\title{
The female condom: Dynamics of use in urban Zimbabwe
}

Deanna Kerrigan

Steve Mobley

Naomi Rutenberg

Population Council

Andrew A. Fisher

Ellen Weiss

Population Council

Follow this and additional works at: https://knowledgecommons.popcouncil.org/departments_sbsr-hiv

Part of the Health Services Research Commons, and the International Public Health Commons How does access to this work benefit you? Let us know!

\section{Recommended Citation}

Kerrigan, Deanna, Steve Mobley, Naomi Rutenberg, Andrew A. Fisher, and Ellen Weiss. 2000. "The female condom: Dynamics of use in urban Zimbabwe," Horizons Report. Washington, DC: Population Council. 


\section{Hgrizons}

\section{The Female Condom Dynamics of Use in Urban Zimbabwe}

Deanna Kerrigan

(P Population Council

Steve Mobley

Naomi Rutenberg

Horizons is implemented by the Population Council in collaboration with - International Center for Research on Women (ICR W)

- International HIV/AIDS Alliance

- Program for Appropriate Technology in Health (PATH)

- The University of Alabama at B irmingham

- Tulane U niversity

Andrew Fisher

Ellen Weiss 


\section{Acknowledgments}

The authors would like to thank the following people and groups for their assistance in conducting the research or in preparing this report: Kerry Richter and Dominique Meekers of PSI/Washington, Kyle Peterson and Sanjay Chiganti of PSI/Zimbabwe, Caroline Trigg of Target Research, Inc., in Zimbabwe, Patrick Osewe of USAID/Zimbabwe, Dr. O. Mugurungi of the National AIDS Coordination Programme of the Ministry of Health in Zimbabwe, Barbara de Zalduondo of USAID/Washington, the Female Condom Working Group in Washington, and Grace Osewe and the participants of the Female Condom Data Interpretation Workshop in Zimbabwe.

USAID

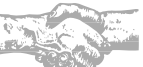

*
This publication was made possible through support provided by the Office of Health and Nutrition, Global Bureau, U.S. Agency for International Development, under the terms of HRN-A-00-9700012-00. The opinions expressed herein are those of the authors and do not necessarily reflect the views of the U.S. Agency for International Development.

Published in October 2000.

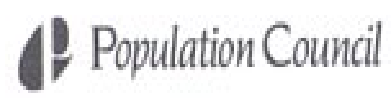

The Population Council is an international, nonprofit, nongovernmental institution that seeks to improve the wellbeing and reproductive health of current and future generations around the world and to help achieve a humane, equitable, and sustainable balance between people and resources. The Council conducts biomedical, social science, and public health research and helps build research capacities in developing countries. Established in 1952, the Council is governed by an international board of trustees. Its New York headquarters supports a global network of regional and country offices.

Copyright (C) 2000 The Population Council Inc. 


\section{Table of Contents}

Executive Summary 1

$\begin{array}{ll}\text { Introduction } & 5\end{array}$

Study Goal and Research Questions 9

$\begin{array}{lr}\text { Methods } & 10\end{array}$

$\begin{array}{lr}\text { Results } & 15\end{array}$

Who Uses the Female Condom in Zimbabwe? $\quad 15$

With Which Types of Partners Is the Female Condom Used? 19

Why Do People Use the Female Condom?

Where Do People Learn About and Obtain the Female Condom? 23

What Attitudes and Perceptions Exist about the Female

Condom and What Difficulties Are Associated with Use? 26

With Whom Is the Female Condom Discussed and How Is its Use Negotiated? 30

How Consistently Is the Female Condom Used? 34

Is the Female Condom a Substitute for the Male Condom? 37

$\begin{array}{lr}\text { Discussion and Recommendations } & 41\end{array}$

$\begin{array}{lr}\text { References } & 48\end{array}$ 


\section{Executive Summary}

$\mathrm{I}$ n July 1997, Population Services International (PSI), at the request of the Zimbabwe National AIDS Coordination Programme (NACP), launched a social marketing program for the female condom in Zimbabwe. To avoid stigma associated with condoms and STI prevention, the female condom was marketed as a family planning product or "contraceptive sheath" under the brand name care $^{\mathrm{TM}}$. The female condom was initially sold through selected pharmacies and clinics at a heavily subsidized retail price of US $\$ 0.24$ for a box of two; distribution has since expanded to other urban outlets, including large supermarkets and convenience stores.

Approximately one year after the start of the female condom social marketing program, the Horizons Project and PSI conducted a descriptive, cross-sectional study of female condom users, male condom users, and non-users of either barrier method. The goal of this research is to increase understanding of the patterns and dynamics of female condom use in order to inform policymakers and program planners involved in decisions about promotion and distribution of the female condom in Zimbabwe.

The study used a combination of quantitative and qualitative methods. An intercept survey was conducted with women and men exiting urban sales outlets that carry both Protector Plus ${ }^{\mathrm{TM}}$ male condoms and $\operatorname{care}^{\mathrm{Tm}}$ female condoms. In total, 493 female condom users, 633 male condom users, and 624 non-users are included in the analyses upon which this report is based. Male and female users of the female condom also participated in in-depth interviews and focus groups.

\section{Results}

\section{Who uses the female condom?}

Users of the female condom are generally in their mid- to late twenties and, compared to male condom users and non-users of either method, have higher levels of education and access to household resources. Among women, more users of the female condom are unmarried and are primary breadwinners in their households compared to male condom users and non-users. A higher percentage of men who have used the female condom are married compared to male users of the male condom. The vast majority of men and women used the male condom at least once prior to trying the female condom. 
More than half of male users of the female condom but only 17 percent of female users reported having more than one sexual partner within the last year. Use of the female condom is higher within the context of marriage or regular partnerships, rather than casual or commercial partnerships.

\section{Reasons for female condom use}

Novelty or experimentation and pregnancy prevention are primary reasons for initial use of the female condom. However, a third of men and 21 percent of women reported STI/ HIV prevention as a motivator for trying the female condom. Radio and friends or relatives are important sources of information about the female condom, but face-to-face contact-either via partners, friends, relatives, or health professionals—is an important motivator of actual use.

\section{Perceptions of and problems with the female condom}

Users of the female condom perceive it to be effective and reliable as both an STI/HIV prevention method and a contraceptive method. But 30 percent of men and 57 percent of women reported some difficulty with use, such as problems with insertion, discomfort during sex, and excess lubrication.

\section{Negotiation of the female condom}

Both male and female users of the female condom concur that women, more than men, initiate dialogue about using the female condom, decide on its use, and procure the product. However, a considerable percentage of both male and female users of the female condom reported that both partners jointly decide to use the female condom. Pregnancy prevention and disease prevention are the most common topics discussed by survey participants in the negotiation process. However, focus group and in-depth interview data reveal that while some women, particularly married women, are interested in the female condom for disease prevention, they are not comfortable discussing this openly with their partner. Instead, they reported using other strategies, such as telling their partner that sex would be more enjoyable than with a male condom, or that sex would be possible during menstruation.

An interesting finding is that 13 percent of women reported using the female condom without their partners' knowledge. While this suggests that for some women the female condom can be totally under their control, in the vast majority of cases the female condom requires communication with and cooperation from a woman's partner. 
Nearly a fourth of women and 15 percent of men said that one of their partners had opposed female condom use. While most said they used a male condom instead, among married women about half whose partner opposed using the female condom had unprotected sex instead.

\section{Consistency of female condom use}

Overall, about 15 percent of women and men reported always using the female condom. Consistent use was reported much less frequently with spouses than with regular partners outside of marriage. Results from multivariate logistic regression demonstrate that female condom users who do not experience difficulties with use or partner opposition to female condoms, do not rely on other family planning methods, and first began using the female condom in order to prevent pregnancy are more likely to be consistent users.

Among those who have used the female condom and the male condom, approximately 80 percent of men said they intend to use both methods in the future. However, a greater proportion of women said they will use the female condom again (68 percent), compared to the male condom (54 percent). But married women were less likely than single women to report continued use of either barrier method.

\section{Increased STI/HIV protection among some female condom users}

Twenty-seven percent of married women had never used a male condom before they used the female condom, (27/98) and 20 percent of consistent female condom users reported that they were not consistent male condom users prior to trying the female condom (13/65).

\section{Continued male condom use among female condom users}

Of inconsistent female condom users who have used the male condom, 93.8 percent reported continued use of the male condom. Qualitative data reveal that female condom users often alternate the use of male and female condoms instead of relying on one method alone. Participants said that what is used is determined by different factors, such as which method is available, what a partner wants to use, whether the woman is in her fertile period, and whether the woman is menstruating. Women also reported using female condoms when their husbands come home late at night or when they suspect infidelity. Additionally, some men reported using female condoms with their wives and regular partners while continuing to use male condoms with casual partners and sex workers. 


\section{Policy Implications}

The female condom has been used within marriage or a regular partnership and among consistent users, primarily as a family planning method, which reflects the aims of the social marketing campaign. Single women and married men with outside partners seem to benefit most from its introduction. These are important groups to reach in a country such as Zimbabwe, which has a high prevalence of HIV in the general population.

However, married women have particular needs that need to be addressed in future campaigns and educational programs. Many married women perceive themselves to be at risk of HIV infection but do not use any barrier method. Among female condom users, married women are more likely than single women to encounter partner resistance to the female condom and less likely to report future use. They also are less likely than single women to have used male condoms prior to trying the female condom and less likely to be consistent female condom users.

Face-to-face contact — with either partners, friends, relatives, or health professionals—was found to be important for motivating female condom use. Training both peer educators as well as clinicians and pharmacists to provide women and men with information and support services about the product may be an effective means of increasing correct and continued use.

Users of the female condom often continue using male condoms. But which method is actually used for a particular act of intercourse is often driven by the context of the situation, with some contexts - such as the suspicion of a woman that her partner is unfaithfulfavoring the use of a female condom. Data from this study suggest that female condoms are providing new and additional protection from HIV/STI to some study participants. More research is needed to more accurately assess the female condom's contribution to increasing the incidence of protected sex among women and men in Zimbabwe. 


\section{Introduction}

T he female condom is a relatively new product that prevents pregnancy and sexually transmitted infections (STIs). The World Health Organization (WHO) estimates a 5 percent annual accidental pregnancy rate associated with perfect use of the female condom, compared to 3 percent with the male condom. ${ }^{1}$ Extrapolations from a study on contraceptive efficacy suggest that perfect use of the female condom also reduces the annual risk of becoming infected with HIV by more than 90 percent among women who have intercourse twice weekly with an infected male, which is similar to the level of protection offered by the male condom. ${ }^{2}$

The female condom may also prove to be an HIV protection option over which women have more control. While male latex condoms are still recommended for STI protection, many women may be unable or unwilling to negotiate male condom use with their sexual partners because of prevailing gender-related inequalities, norms, and roles that exist in many sociocultural contexts. ${ }^{3}$ Given the steady increase in the percentage of persons infected with HIV who are adult women and the rising global rates of HIV infection, policymakers, program planners, community members, and other stakeholders have lobbied for the availability of HIV/ STI prevention methods that may be easier for women to negotiate and control than the male condom. ${ }^{4}$
${ }^{1}$ World Health Organization (WHO) and UNAIDS. 2000. The Female Condom: $A$ Guide for Planning and Programming. Geneva, Switzerland: UNAIDS.

\footnotetext{
${ }^{3}$ Family Health International. 2000. Kenya: Female Condom Use and the Incidence of Sexually Transmitted Infections. Arlington, VA: Family Health International.

${ }^{4}$ UNAIDS (Joint United Nations Programme on HIV/AIDS). 2000. Report on the Global HIV/AIDS Epidemic. Geneva, Switzerland: UNAIDS.
} 
Several studies have assessed the acceptability of the female condom in distinct cultural contexts and have found it to be a viable and acceptable contraceptive and HIV prevention method to high percentages of both men and women. ${ }^{5}$ These high levels of initial acceptance and interest in the female condom have sparked continued advocacy and program planning efforts to expand access to the product as well as operations research to explore the dynamics of female condom use and assess its role in reducing STIs and HIV infection.

\section{Background}

In 1993, the University of Zimbabwe's Department of Community Medicine received funding from WHO to conduct an acceptability study of the female condom in Zimbabwe with sex workers, urban women attending a family planning clinic, and rural women in long-term relationships. Approximately 200 women were interviewed at baseline, supplied with female and male condoms, and trained in how to use them. Follow-up interviews and focus groups investigated participants' experiences with the female condom over time.

Study findings reveal that the large majority of women in all three groups and their male partners "liked the female condom very much," and in fact preferred it to the male condom. Less than 10 percent did not like the device. Other key findings include participant reports that the female condom (1) offers a measure of control the women haven't experienced before, (2) is perceived as providing greater protection than the male condom because of its strength and resistance to breaking, and (3) becomes easier to use with practice, despite such initial complaints as difficulty of insertion and discomfort. ${ }^{6}$

\footnotetext{
${ }^{5}$ Kabira, W. et al. 1997. The Female Condom as a Female-Controlled Protective Method: Nairobi, Kenya. AIDSCAP Project. Arlington, VA: Family Health International. Kalckmann, A. et al. 1997. The Female Condom as a Female-Controlled Protective Method: São Paulo, Brazil. AIDSCAP Project. Arlington, VA: Family Health International. Rogers, C, et al. 1997. "The female condom: counseling women in successful use of the newest method of barrier protection from STD/HIV that puts control into the hands of the woman," paper presented at the National Conference on Women and HIV, Pasadena, California, 4-7 May.

Xu, J.X. et al. 1998. "User acceptability of a female condom (Reality) in Shanghai," Advances in Contraception 14(4): 193-99.
}

\footnotetext{
${ }^{6}$ Ray, S. et al. 1995. "Acceptability of the female condom in Zimbabwe: Positive but male-centered responses," Reproductive Health Matters 5: 494-503.
} 
have arisen about its use and its potential for STI/HIV reduction. Who uses the female condom, with whom, and why? How is use negotiated? And what are the frequency and protective effect of female condom use?

Answers to these and other related questions have important implications for reproductive health programs. Currently, the female condom is a relatively expensive product, approximately ten times the cost of a male condom. ${ }^{11}$ From a program and policy standpoint, the decision to introduce this product in a given country on a wide scale implies significant financial costs. Program managers and policymakers may see these costs as fully justified if the product offers added protection from pregnancy and disease. For example, even in situations where the frequency of female condom use is relatively low compared with the male condom, the cost of the female condom to a national program might be justifiable if use occurs in situations that otherwise might result in unprotected sex and exposure to STIs, including HIV. On the other hand, the cost may be seen as excessive if the female condom is merely a substitute for the male condom, or if it is used as a novelty item once or twice and not thereafter.

The introduction of heavily subsidized and relatively inexpensive female condoms in Zimbabwe through a social marketing program has provided large numbers of urban women with easy access to this product. Unlike settings in other countries where the female condom has been introduced on a very limited pilot basis to a few hundred women, the situation in Zimbabwe allowed the Horizons Project and PSI to address critical research questions with a fairly large number of respondents about female condom use under real-life conditions. 


\section{Study Goal and Research Questions}

he overall goal of this study is to increase public understanding of the patterns and dynamics of female condom use in Zimbabwe in order to help policymakers and program planners make decisions about promotion and distribution of the female condom in Zimbabwe.

The study sought to address the following research questions:

- Who uses the female condom in Zimbabwe?

With which types of sexual partners is the female condom used?

Why do people use the female condom?

Where do people learn about and obtain the female condom?

- What attitudes and perceptions exist about the female condom and what difficulties are associated with use?

With whom is the female condom discussed and how is its use negotiated?

- How consistently is the female condom used?

Is the female condom a substitute for the male condom? 


\title{
Methods
}

\begin{abstract}
his study used a combination of quantitative and qualitative methods. The methodology of the quantitative survey is described first, followed by an overview of the qualitative methods.
\end{abstract}

\section{Survey Methodology}

\section{Sampling and selection criteria}

Data collection and data management were subcontracted to a local research organization, Target Research, Inc. Target Research, the Horizons Project, and PSI worked together to develop the study's sampling strategy and data collection instruments. The sampling strategy was designed to obtain a representative sample of 500 female and 1,000 male condom users as well as 1,000 non-users of either method. All female condom users were recruited in urban areas of Zimbabwe, including Harare, Bulawayo, and Mutare, while 40 percent of male condom users and non-users were recruited in rural areas, where male condoms-unlike female condoms - are distributed widely. It is important to note, however, that this report pertains only to consumers from urban areas, and thus the sample of male condom users and non-users of either method is smaller than a thousand.

Study sites included urban sales outlets that carried both the PSI Protector Plus ${ }^{\mathrm{TM}}$ male condoms and care ${ }^{\mathrm{TM}}$ female condoms in the last three months. Four types of sales outlets were included in the study: pharmacies, supermarkets, small stores, and such non-traditional outlets as service stations, department stores, and beer halls. PSI provided the research team with a complete list of all such outlets that had sold female condoms in the last three months. Eligible outlets were then randomly selected for participation by selecting every third outlet from this list.

Study participants were selected from among urban consumers leaving each of the participating outlets. A screening questionnaire was used to select potential respondents. Study selection criteria required that participants were sexually active within the last 12 months and be between 16-44 years old in the case of women and 16-49 in the case of men. Interviewers then determined whether potential respondents had used either barrier method or no barrier method in the last 12 months. 
Anyone who has ever used a female condom was interviewed ("ever users"). Among the remaining two groups (male condom users and non-users), only one in ten was interviewed. This strategy was constructed based on estimates from a pilot study conducted among men and women exiting Harare pharmacies that indicates that approximately 3 to 4 percent of this population had ever used the female condom. If every male condom user or non-user had been interviewed, 600 of each group would have had to be interviewed to obtain a representative sample of approximately 500 female condom users.

In practice, fewer than 2 percent of those intercepted outside urban outlets where the female condom was sold reported that they had tried it. By the time the survey of the male condom users and non-users was completed, only 275 users of the female condom had been interviewed. At that stage, in order to obtain the required number of female condom users in the most cost-effective way, the study opted to focus only on the busiest pharmacies and supermarkets where the female condom is sold. In total, 493 female condom users, 633 male condom users, and 624 non-users are included in the analyses upon which this report is based.

\section{Recruitment}

Because the questionnaire contained personal and sexual content, interviewers were of the same sex as the respondent. Thus a team of two interviewers, one male and one female, was posted at each outlet at a time. Interviewers were stationed at participating outlets during the full period of time that the outlet was open. The interviewer team recruited study participants based on the following criteria:

- The first person who appeared to be of the appropriate age group to leave the outlet unaccompanied was approached by the interviewer of the same sex.

- The screening questionnaire established whether the person was in the correct age group, was sexually active (in the past 12 months), and had ever used a female condom with a partner or had used a male condom in the past 12 months.

- While one interviewer talked to or actually interviewed a potential respondent, the other interviewer did not approach anyone but instead kept a count of how many males and females who appeared to be in the appropriate age group left the outlet. This was done to get some idea about the relative volume of business at each outlet and to ensure that the ratio of males to females interviewed was the same as the ratio of males to females frequenting the outlet. 
- When the interviewer who was screening and/or interviewing someone had finished, the next person of the appropriate age group to leave the outlet was selected and interviewed by the interviewer of the same sex.

\section{Data collection instruments}

Structured questionnaires were developed for the study and were pre-tested in the field to ensure that they were clear and unambiguous and took no more than 20 minutes to administer. Translators employed by the University of Zimbabwe's Population Demographics Department produced translations and back-translations of the instruments from English into Shona and Ndebele. All translated versions of the surveys were also tested in the field before they were finalized. Respondents chose the language they wanted to use for the interview.

Different survey instruments were used for each of the three sub-groups (female condom users, male condom users, and non-users of either method) and included questions on the following topics, as appropriate, given the participant's experience or lack of experience with the female or male condom:

- Demographic information such as sex, age, marital status, number of children, and socioeconomic status.

- HIV/STI-related perceptions and sexual behavior such as perceived risk of HIV infection, number of sexual partners, types of sexual partners, condom use per partner type (spouse, regular partner outside of marriage, casual acquaintance, and sex worker in the case of men) and consistency of condom use.

- Attitudes and communication strategies regarding both the female and male condom.

All survey data were collected during the period of August to December 1998. 


\section{Weighted data}

The data presented in this report were weighted to approximate a representative sample of consumers by sex, type of outlet, and location. Weighting accounts for the varying numbers of consumers at different outlets. To make the sample representative of all consumers, respondents at outlets with greater traffic were given greater weight than those at outlets with fewer consumers. In short, if the outlet type, location, and sex category had a larger proportion of consumers than is reflected in the number of respondents contacted in that category, the weight is greater than one and the respondent in that category is weighted more heavily. If it had a smaller proportion of consumers than the proportion of respondents in the sample, the weight is less than one.

\section{Training and supervision of interviewers}

The initial data collection team included 46 interviewers (23 males and 23 females), with 24 interviewers working in Harare, 10 interviewers working in Bulawayo, 6 in Gweru, and 6 in Mutare. An additional six interviewers provided backup and replacement when core interviewers were sick or experienced difficulty with their work.

All interviewers received initial training from the study coordinators before beginning data collection in the field. Additionally, the study director and support staff conducted briefings and debriefings periodically in each of these towns to assess data collection progress and potential barriers to implementation. Supervisory support was provided in each of the towns, and a team of field supervisors visited, on a random basis, the outlets at which interviewers were posted to check whether they were there and whether they were intercepting and interviewing people as instructed.

\section{Confidentiality and informed consent}

Interviews were anonymous, with no identifying information such as names or addresses collected from any respondent. Oral informed consent was obtained in the respondent's local language. The interviewers read the informed consent form to respondents and answered any questions the respondent may have had about it and the study. The investigator signed a form that was attached to the completed data collection instrument attesting to the fact that the investigator read the informed consent form to the respondent and that the respondent agreed to participate. 


\section{Qualitative methods}

Both individual in-depth interviews and focus groups took place during the period of January to March 1999 as part of this study. Five men and eleven women who had previously used the female condom with one of their sexual partners participated in individual in-depth interviews. Preliminary findings from the quantitative survey reveal that more married men and single women use the female condom than single men and married women. Thus a purposive sample of three married and two single men and seven single and four married women were selected to participate in in-depth interviews. Two of the men and two of the women were interviewed in Bulawayo and the rest were interviewed in Harare. Each interview was conducted in private and took between 1.5 to 3 hours to complete. Topics regarding female condom use covered by the in-depth interviews included communication patterns, first and subsequent experiences with use, reasons for use, perceptions of the female condom, and difficulties with use.

In addition to individual in-depth interviews, four focus groups-two groups of men and two groups of women-were held with female condom users. Each group contained between seven and eleven persons. Focus groups were private and lasted between 1.5 to 2 hours on average. Female condom-related topics discussed in focus groups included ease of introduction, social perceptions and stigma, the impact of female condom use on couple communication, and awareness and understanding of advertisements.

All participants involved in both in-depth interview and focus groups gave informed consent before any data collection began. 


\section{Results}

S

urvey results are presented under the eight research questions, with qualitative results integrated into each section. All quantitative data analysis leading to the results presented below used weighted data; hence, the "Ns" found in the tables below may vary slightly from the total number of study participants in each sub-group, as discussed previously.

\section{Who Uses the Female Condom in Zimbabwe?}

\section{Demographic characteristics}

Table 1 presents a profile of study participants: female condom ever users, male condom ever users, and non-users of barrier methods. The average age of female study participants is similar across the three sub-groups: 27.4 among female condom users, 26.7 among male condom users, and 26.5 among non-users. Among men, female condom users and non-users are somewhat older, with average ages of 29.8 and 31.7, respectively, than users of the male condom, with an average age of 27.0. The marital status of respondents varies across these three groups. Among women, 58.7 percent of female condom users are unmarried, compared to 41.5 percent of male condom users and 24.8 percent of non-users of barrier methods. Among men, 54.3 percent of male condom users are unmarried, compared to 39.5 percent of female condom users and 18.7 percent of non-users of barrier methods.

On average, female condom users have had more formal education than male condom users or non-users. Among women, 44.9 percent of female condom users have had a post-secondary education, compared to 19.2 percent of male condom users and 12.6 percent of non-users of barrier methods. Similar to the pattern seen with women, 49.4 percent of female condom users among men have had post-secondary education, compared to 29.6 percent of male condom users and 25.1 percent of non-users.

Socioeconomic status is also greatest among users of the female condom. The measure of socioeconomic status used is an additive index of ownership of such goods as a radio, TV, bicycle, motorcycle, car, refrigerator, freezer, and stove. The average score on this nine-point index is 4.2 to 4.3 among female condom users, compared to 3.4 to 3.5 among male condom users and 2.9 to 3.3 among non-users. Additionally, more female users of the female condom reported being the primary breadwinner in their household (39.7 percent) compared to female users of the male condom (28.8 percent) or non-users of barrier methods (13.8 percent). 
Table 1: Demographic characteristics

\begin{tabular}{|c|c|c|c|c|c|c|}
\hline \multirow{2}{*}{$\begin{array}{l}\text { Percent (\%) } \\
\text { Variable }\end{array}$} & \multicolumn{2}{|c|}{$\begin{array}{l}\text { Female condom users } \\
(\mathrm{N}=493)\end{array}$} & \multicolumn{2}{|c|}{$\begin{array}{l}\text { Male condom } \\
(\mathrm{N}=633)\end{array}$} & \multicolumn{2}{|c|}{$\begin{array}{l}\text { Non-users } \\
(\mathrm{N}=624)\end{array}$} \\
\hline & $\begin{array}{l}\text { Male } \\
(\mathrm{N}=256)\end{array}$ & $\begin{array}{l}\text { Female } \\
(\mathrm{N}=237)\end{array}$ & $\begin{array}{l}\text { Male } \\
(\mathrm{N}=431)\end{array}$ & $\begin{array}{l}\text { Female } \\
(\mathrm{N}=202)\end{array}$ & $\begin{array}{l}\text { Male } \\
(\mathrm{N}=291)\end{array}$ & $\begin{array}{l}\text { Female } \\
(\mathrm{N}=333)\end{array}$ \\
\hline \multicolumn{7}{|l|}{ Age } \\
\hline $16-19$ & 3.8 & 8.5 & 5.3 & 7.6 & 4.2 & 12.3 \\
\hline $20-24$ & 20.9 & 28.8 & 39.5 & 33.5 & 15.4 & 34.7 \\
\hline $25-29$ & 26.6 & 32.5 & 26.2 & 32.3 & 26.3 & 26.7 \\
\hline $30-34$ & 24.0 & 14.8 & 13.7 & 12.7 & 19.9 & 12.3 \\
\hline $35-44 f / 49 m$ & 24.6 & 15.3 & 15.4 & 14.0 & 34.3 & 14.0 \\
\hline Mean & 29.8 & 27.4 & 27.0 & 26.7 & 31.7 & 26.5 \\
\hline Median & 29.0 & 26.0 & 25.0 & 25.6 & 30.0 & 25.0 \\
\hline \multicolumn{7}{|l|}{ Marital status } \\
\hline Unmarried & 39.5 & 58.7 & 54.3 & 41.5 & 18.7 & 24.8 \\
\hline \multicolumn{7}{|l|}{ Education level } \\
\hline $\begin{array}{l}\text { Less than } \\
\text { secondary }\end{array}$ & 8.3 & 15.7 & 16.4 & 33.7 & 27.6 & 40.2 \\
\hline Secondary & 42.3 & 39.4 & 54.0 & 47.1 & 47.3 & 47.2 \\
\hline Post-secondary & 49.4 & 44.9 & 29.6 & 19.2 & 25.1 & 12.6 \\
\hline \multicolumn{7}{|l|}{ Breadwinner } \\
\hline $\begin{array}{l}\text { Is the main } \\
\text { breadwinner in } \\
\text { household }\end{array}$ & 78.2 & 39.7 & 61.7 & 28.8 & 85.8 & 13.2 \\
\hline \multicolumn{7}{|c|}{ Socioeconomic status (nine item index of household resources) } \\
\hline Low: $\quad 0-2$ & 22.2 & 21.1 & 36.6 & 37.5 & 37.3 & 50.3 \\
\hline Medium: 3-5 & 51.9 & 47.7 & 46.8 & 45.7 & 51.4 & 36.0 \\
\hline High: $\quad 6-9$ & 25.9 & 31.3 & 16.6 & 16.9 & 11.3 & 13.7 \\
\hline Mean & 4.2 & 4.3 & 3.5 & 3.4 & 3.3 & 2.9 \\
\hline Median & 4.0 & 4.0 & 3.0 & 3.0 & 3.0 & 2.0 \\
\hline \multicolumn{7}{|c|}{ Number of children } \\
\hline 0 & 33.7 & 36.5 & 51.9 & 20.6 & 22. & 23.0 \\
\hline 1 & 25.7 & 23.5 & 18.5 & 34.2 & 25.0 & 33.0 \\
\hline 2 & 20.2 & 22.9 & 14.6 & 28.1 & 20.8 & 23.3 \\
\hline $3+$ & 20.4 & 17.2 & 15.0 & 17.2 & 31.3 & 20.7 \\
\hline Mean & 1.4 & 1.3 & 1.0 & 1.5 & 2.1 & 1.6 \\
\hline Median & 1.0 & 1.0 & .00 & 1.00 & 2.0 & 1.0 \\
\hline
\end{tabular}


The number of children reported by women across the three groups is similar, with female condom users averaging slightly fewer (1.3) than male condom users (1.5) and non-users (1.6). Additionally, more female users of the female condom reported having no children ( 36.5 percent) than female users of the male condom (20.6 percent) and non-users (23.0 percent). Among men, the average number of children reported is 1.4 for female condom users, 1.0 for male condom users, and 2.1 for non-users.

Summarizing the profile of female condom users on the basis of these standard demographic variables, users of the female condom are generally young women and men in their mid- to late twenties. Compared to users of the male condom and non-users of barrier methods, female condom users (both female and male) have higher levels of education and access to household resources. Additionally, more female users of the female condom are unmarried and are primary breadwinners in their households compared to female users of the male condom and female non-users of barrier methods.

It is important to emphasize that the characteristics of female condom users presented in this study may not be generalizable to other countries or other settings. At the time of this study, the female condom was socially marketed in urban Zimbabwe through radio, TV, and print media and sold in shopping outlets, with limited free distribution of the product through public health clinics. The study sample represents people from urban areas who were consumers at shopping outlets where the female condom was sold.

\section{HIV behavior and related risk perception}

As seen in Table 2, male condom users had the highest average number of sexual partners in the last year. Among men, male condom users averaged 3.72 partners in the last year, compared to 2.45 among female condom users and 1.15 among non-users. Across the three groups, the number of men reporting only one sexual partner in the last year varies: 85.6 percent of male non-users reported one partner in the last year, compared to 45.8 percent of female condom users and 29.8 percent of male condom users. Among women, male condom users averaged 1.65 partners in the last year, compared to 1.58 among female condom users and 1.08 among non-users. More than 80 percent of women from each of the three groups reported having only one sexual partner in the last year.

Overall, male condom users reported higher perceived risk of HIV infection than female condom users and non-users. Among male condom users, 26.9 percent of men and 23.5 percent of women perceive themselves at moderate or great risk of infection, compared to 
22.7 percent of men and 16.0 percent of women among female condom users. Among non-users, 12.6 of men and 25.7 percent of women reported moderate to great risk of HIV infection.

While the lowest perceived risk of HIV infection was reported by male non-users, one of the highest was reported by female non-users. This finding warrants further investigation. Women who are not using any barrier method but are fearful of contracting HIV/AIDS may find it difficult to negotiate protective measures with their husbands or male partners and hence may be in need of tailored interventions and support services.

Across all user groups and both sexes, the vast majority of study participants reported knowing someone who has AIDS or has died from HIV/AIDS, revealing the scope of the epidemic in Zimbabwe. Among women, 91.5 of female condom users, 92.1 percent of male condom users, and 82.9 percent of non-users know someone with HIV/AIDS. Among men, 95.4 percent of female condom users, 85.4 of male condom users, and 85.0 percent of non-users know someone with HIV/AIDS.

Table 2: HIV-related behavior and risk perceptions

\begin{tabular}{|c|c|c|c|c|c|c|}
\hline Percent (\%) & \multicolumn{2}{|c|}{$\begin{array}{l}\text { Female condom users } \\
(\mathrm{N}=493)\end{array}$} & \multicolumn{2}{|c|}{$\begin{array}{l}\text { Male condom users } \\
(\mathrm{N}=633)\end{array}$} & \multicolumn{2}{|c|}{$\begin{array}{l}\text { Non-users } \\
(\mathrm{N}=624)\end{array}$} \\
\hline Variable & $\begin{array}{l}\text { Male } \\
(N=256)\end{array}$ & $\begin{array}{l}\text { Female } \\
(\mathrm{N}=237)\end{array}$ & $\begin{array}{l}\text { Male } \\
(\mathrm{N}=431)\end{array}$ & $\begin{array}{l}\text { Female } \\
(\mathrm{N}=202)\end{array}$ & $\begin{array}{l}\text { Male } \\
(\mathrm{N}=291)\end{array}$ & $\begin{array}{l}\text { Female } \\
(\mathrm{N}=333)\end{array}$ \\
\hline \multicolumn{7}{|c|}{ Number of sexual partners in the last year } \\
\hline 1 & 45.8 & 82.7 & 29.8 & 81.5 & 85.6 & 94.7 \\
\hline 2 & 26.9 & 10.6 & 26.3 & 11.8 & 10.5 & 2.6 \\
\hline $3+$ & 27.3 & 6.7 & 43.9 & 6.7 & 3.9 & 2.7 \\
\hline Mean & 2.45 & 1.58 & 3.72 & 1.65 & 1.15 & 1.08 \\
\hline Median & 2.00 & 1.00 & 2.00 & 1.00 & 1.00 & 1.00 \\
\hline \multicolumn{7}{|c|}{ Perceived risk of HIV infection } \\
\hline None & 29.5 & 29.3 & 28.3 & 29.8 & 47.4 & 28.2 \\
\hline Small & 37.1 & 40.3 & 31.2 & 29.7 & 22.8 & 23.8 \\
\hline $\begin{array}{l}\text { Moderate or } \\
\text { great }\end{array}$ & 22.7 & 16.0 & 26.9 & 23.6 & 12.6 & 25.7 \\
\hline Don't know & 10.7 & 14.4 & 13.6 & 16.9 & 17.2 & 22.3 \\
\hline \multicolumn{7}{|c|}{ Knows someone who has AIDS or has died from HIVIAIDS } \\
\hline Yes & 95.4 & 91.5 & 85.4 & 92.1 & 85.0 & 82.9 \\
\hline
\end{tabular}




\section{With Which Types of Partners Is the Female Condom Used?}

Table 3 documents the types of sexual partners that female condom users had in the last 12 months and with which of those partners they used female condoms. Partner types and condom use are examined across sex and marital status within the female condom user sample. As expected, more than 95 percent of married men and women have had sex with their spouses in the last year. A higher percentage of married women had used the female condom with their spouse (96.1 percent), compared to married men (73.6 percent). Most married women (91.1 percent) reported being monogamous with their husbands and thus would have the opportunity to use the female condom only with their spouses, whereas more than half of married men (54.1 percent) reported having more than one sexual partner in the last 12 months and would thus have had the opportunity to use the product with other types of partners.

As shown in Table 3, approximately one-third (35.4 percent) of married men who have used the female condom reported they have had a regular partner other than a spouse. Among all married men, 32.8 percent had used the female condom with a regular partner, indicating that a very high percentage of married men who have a regular partner (92.6 percent) have used the female condom with such partners. Nine percent of married women reported having a regular partner and 8.2 percent have used the female condom with a regular partner, indicating that the large majority have tried the product with that partner (91.1 percent). Most unmarried female condom users participating in the study reported having a regular sexual partner: 89.5 percent of men and 88.5 percent of women. Among all unmarried participants, 78.2 percent of men and 86.5 percent of women have used the female condom with a regular partner. Thus, 87.4 percent of men and 97.7 percent of women who are unmarried and have a regular partner have used the female condom with these partners. 
Table 3: Sexual relations and female condom use per partner type

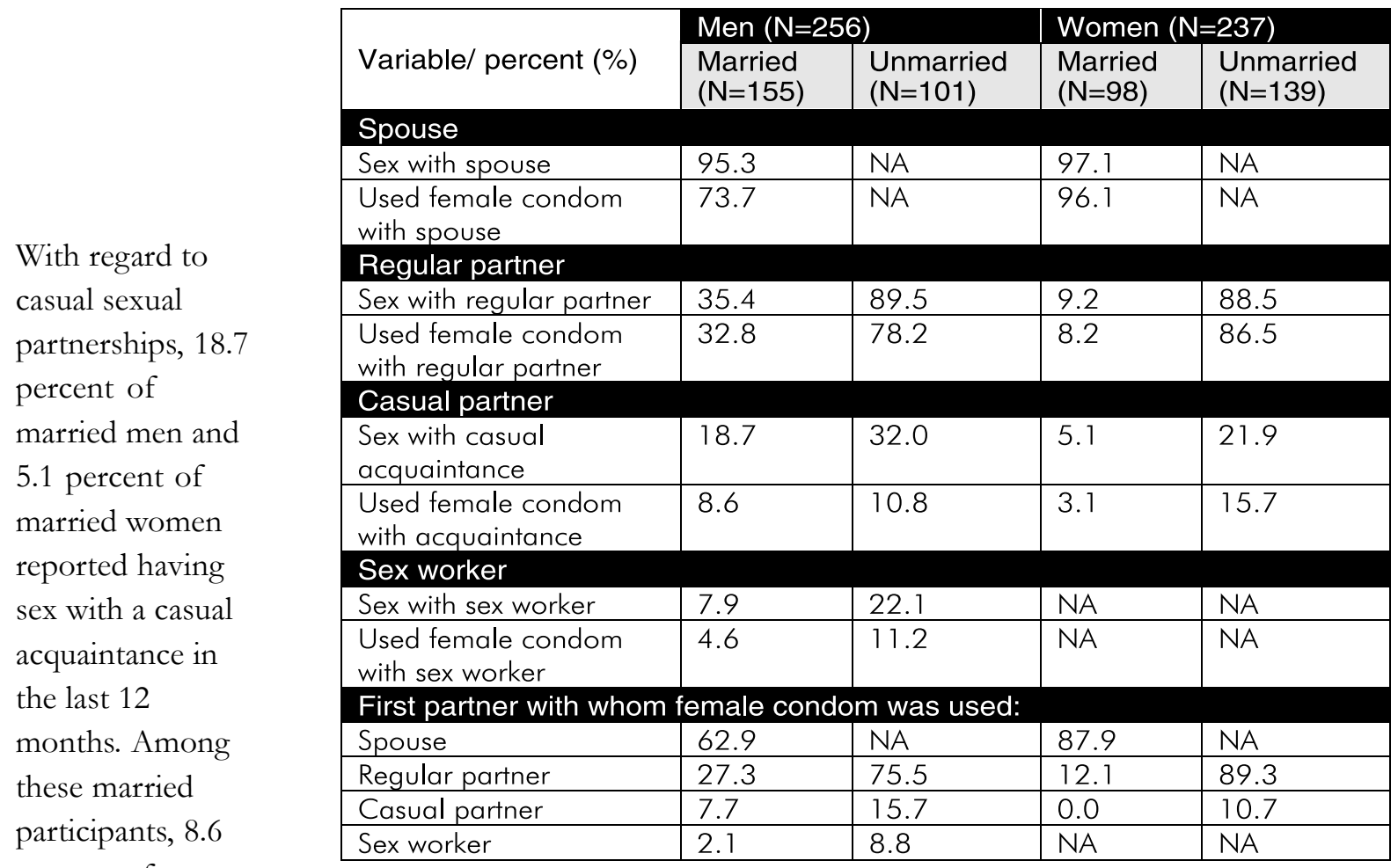

percent of men

and 3.1 percent of women reported using the female con-

dom with a casual acquaintance; hence, 45.9 percent of

married men and 60.8 percent of married women with casual

partners reported ever using the female condom with them.

Among unmarried participants, 32.9 percent of men and

21.9 percent of women reported having a casual sex partner

in the last 12 months. Among these unmarried participants,

10.8 percent of men and 15.7 percent of women reported using the female condom with a casual acquaintance; thus, 32.8 percent of unmarried men and 71.7 percent of unmarried women with casual partners reported ever using the female condom with them.

Only male participants were asked if they had had sex with a sex worker in the last 12 months. Eight percent of married men and 22.1 percent of unmarried men reported having sex with a sex worker, and 4.6 percent and 11.2 percent, respectively, had used the female condom with a sex worker. Hence, 57.5 percent of married men and 50.7 percent of unmarried men who had had sex with a sex worker in the last 12 months had ever used the female condom with that partner type. 
In summary, approximately half of male users of the female condom participating in this study have had more than one type of sexual partner within the last year. The majority of female study participants who have ever used the female condom had only one partner in the last year, generally a spouse or regular partner. Among those participants who reported having sex with a particular type of partner, the percent who tried the female condom with that partner is higher within the context of marriage or regular partnerships rather than within casual or commercial partnerships. These findings may be a reflection of the fact that in Zimbabwe the female condom has been marketed as an appropriate contraceptive method for couples in stable relationships. However, it is also possible that users feel more able to negotiate and use the female condom with persons with whom they have an established relationship.

\section{Why Do People Use the Female Condom?}

Female condom users in the study listened to a list of potential reasons for first using the female condom and who or what first made them decide to use it. Participants could choose more than one of the responses and add their own. With regard to who or what first prompted use, only the most frequent responses are discussed below.

As shown in Figure 1, more than 50 percent of both men and women reported that they first used the female condom because of its novelty or for experimentation. Pregnancy prevention was mentioned as a reason for use by 45.8 percent of men and 34.5 percent of women. Thirty-six percent of men and 21.1 percent of women mentioned HIV/AIDS or STI prevention as the reason they first used the female condom. These latter percentages are relatively high, given that care $^{\mathrm{TM}}$ was marketed in Zimbabwe as a contraceptive device rather than a disease prevention tool. Relatively small percentages of men and women, 4.5 and 1.9, respectively, first used the female condom in an attempt to increase sexual pleasure.

When asked who or what first made them decide to use the female condom, participants often reported that their partner had suggested its use (Figure 2). However, a higher percentage of men (55.2 percent) than women (29.8 percent) said that their partners had suggested female condom use to them. Both men and women (15.6 percent and 20.0 percent, respectively) reported that friends and family members encouraged initial female condom use. Participants also mentioned such stimuli as advertisements, store displays, and radio spots as additional motivators for initial use. 
Qualitative in-depth interview data corroborate survey findings about motivations for initial use. For example, three out of the five male in-depth interview participants said that they just wanted to see what the female condom felt like and/or see how it compares to the male condom. One man reported that he and his partner had begun using the female condom when his partner was menstruating so they could still have
Figure 1: Reasons for initial female condom use

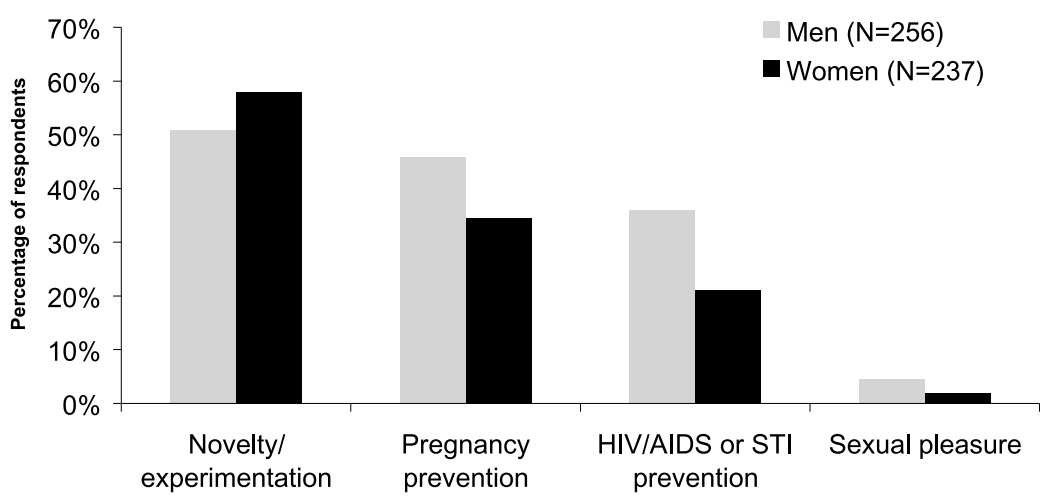
sex during this time. One of the other male in-depth interview participants said that his female partner began to use the female condom as an alternative contraceptive method when she began to have problems using oral contraceptives. However, when men were then asked, "What is the main reason you use care?" (in general versus the first time), all five said that it was because of HIV prevention.

Figure 2: Who or what first made participants decide to use the female condom

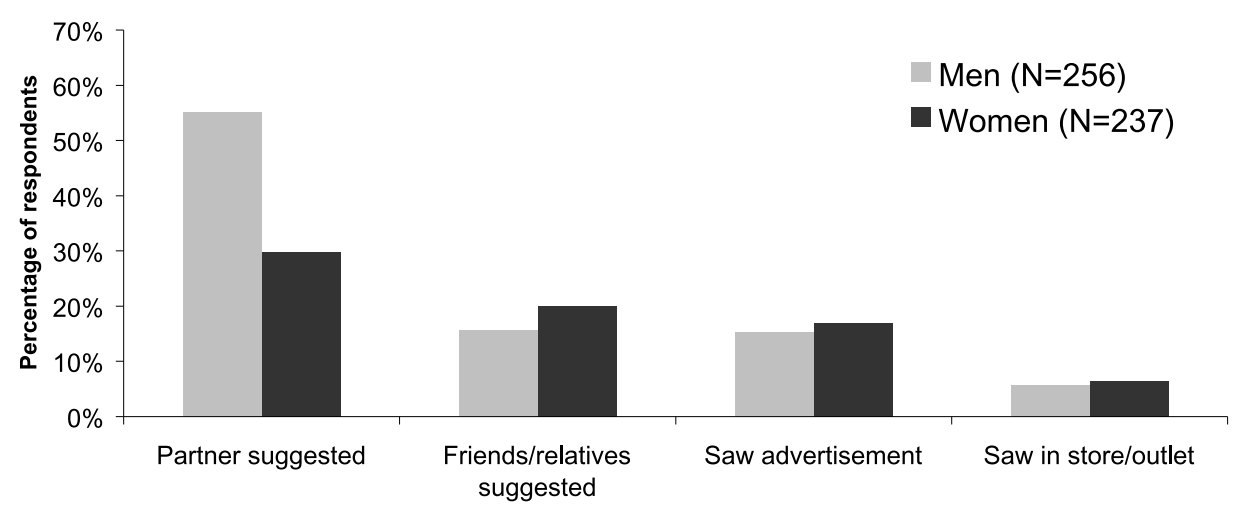

Of the women participating in the in-depth interviews, the two who reported using the female condom with casual partners said that their reason for initial use was HIV prevention and that they discussed this reason openly with their partners. The other nine women who had used the female condom with their husbands or regular partners stated that while they themselves were interested in disease prevention, none of them initially discussed disease prevention with their partners. When asked, "What is the main reason you use the female condom?" (in general versus the first time), more women mentioned family planning than disease prevention, with just a few naming novelty or experi- 
mentation. The majority of both male and female focus group participants also said prevention of sexually transmitted diseases is their main reason for using the female condom. Several female focus group participants also said that the female condom offers a welcome alternative to hormonal methods of contraception.

\section{Where Do People Learn About and Obtain the Female Condom?}

Female condom users were asked where they first heard about the product. Respondents were allowed to report more than one initial information source.

As shown in Table 4, radio was the most common form of mass media from which female condom users first heard about the product. Almost equal percentages of men and women (44.5 and 46.0, respectively) reported having first heard about the female condom on the radio. TV was about half as popular as radio: 21.9 percent of men and 20.7 percent of women reported having first heard about the female condom via TV news reports on the product shown on local stations. TV spots promoting the female condom were not sponsored by PSI, the agency implementing the media campaign for the product at the time of the study.

Higher percentages of men than women first learned about the female condom from printed materials. Approximately one-quarter of male users of the female condom reportedly first learned about the product from a newspaper, magazine, or poster. Among women, 14.8 percent reported that they first heard about the female condom from a magazine; 5.5 percent reported a newspaper and 16.8 percent a poster as the first source. 
Many more women than men reported first becoming aware of the female condom at outlets where the product is sold or from health care institutions or providers. For example, 52.7 percent of women first heard about the female condom from a clinic, hospital, or doctor, compared to 26.1 percent of men. Similar percentages of men and women first heard about the female condom from friends and relatives (54.7 percent and 52.8 percent) and partners (29.4 percent and 27.8 percent).

In general, men and women give similar responses when asked where they last obtained female condom supplies. The most frequently mentioned supply site for both men and women is a pharmacy, where 51.4 percent of men and 47.5 percent of women reported last obtaining the female condom. The second most frequently reported supply site is the supermarket or local store, the source for 18.8 percent of men and 19.3 percent of women.

Participants were also asked if they had received information about how to use the female condom prior to first use. Among women, 86.9 percent of married women and 81.6 percent of unmarried women said they had received information prior to use. Compared to women, 54.6 percent of married men and 60.4 percent of unmarried men reported lower rates of prior information on female condom use. The majority of users said that they received this information from the brochure in the female condom package.

While most female in-depth interview participants said that they received "adequate" information about how to use the female condom, several women said that they would like more information about such issues as the composition and safety of the lubricant that came with the female condom, the issue of reuse, and if and how the device can be used without the knowledge of one's partner. Several male in-depth interview participants said they read the instructions on how to use the device only after their partners had experienced difficulties with use and asked for help.

In summary, almost half of female condom users first heard of the female condom via friends and relatives or radio messages. Awareness of the female condom from print materials is more common among men than women. Yet awareness of the female condom from health clinics and doctors is more common among women than men. Most participants last obtained the female condom from a pharmacy or supermarket, and more women than men received information on how to use the female condom prior to initial use. 
Table 4: Sources of information and supplies of female condom

\begin{tabular}{|c|c|c|}
\hline Variables/percent (\%) & Men $(\mathrm{N}=256)$ & Women $(\mathrm{N}=237)$ \\
\hline \multicolumn{3}{|c|}{ Where did users first hear about the female condom* } \\
\hline \multicolumn{3}{|c|}{ Mass media } \\
\hline Radio & 44.5 & 46.0 \\
\hline TV & 21.9 & 20.7 \\
\hline \multicolumn{3}{|l|}{ Print materials } \\
\hline Magazines & 24.2 & 14.8 \\
\hline Newspapers & 23.0 & 5.5 \\
\hline Posters & 25.3 & 16.8 \\
\hline \multicolumn{3}{|c|}{ Locations/institutions/providers } \\
\hline Sales outlets & 24.3 & 41.2 \\
\hline Clinics/hospitals/doctors & 26.1 & 52.7 \\
\hline \multicolumn{3}{|l|}{ Social contacts } \\
\hline Friends or relatives & 54.7 & 52.8 \\
\hline Partners & 29.4 & 27.8 \\
\hline \multicolumn{3}{|c|}{ Where was female condom obtained upon last use } \\
\hline Pharmacy & 51.4 & 47.5 \\
\hline Supermarket/store & 18.8 & 19.3 \\
\hline Family planning clinic & 4.0 & 7.7 \\
\hline Partner & 4.7 & 2.3 \\
\hline Friend or relative & 1.2 & 3.1 \\
\hline Other & 5.5 & 2.7 \\
\hline Don't know & 14.4 & 17.4 \\
\hline
\end{tabular}

*Participants were allowed to give more than one initial source of information. 


\section{What Attitudes and Perceptions Exist About the Female Condom and What Difficulties Are Associated with Use?}

Study participants' attitudes about the both female and male condoms were assessed through both independent and comparative questions relating to each barrier method. Study participants answered two sets of questions about their perceptions of these two methods. The questions examine the perceived effectiveness of each as STI/HIV prevention and contraceptive methods as well as perceived ease of use, reliability, and affordability. Table 5 compares the attitudes of female condom users, male condom users, and non-users of barrier methods about both the female condom and the male condom.

With regard to STI/HIV prevention, 78.1 percent of male and 84.8 percent of female users of the female condom perceive the female condom as an effective barrier to STI/HIV. Perceived effectiveness of the female condom as a barrier to STI/HIV is considerably lower among male condom users and non-users. For example, among male condom users, 47.1 percent of men and 54.0 percent of women perceive the female condom as an effective barrier method to protect against STI/HIV. Among non-users, 26.5 percent of men and 41.9 percent of women perceive the female condom as an effective barrier against STI/HIV. However, the perceived effectiveness of the male condom as a barrier method against STI/HIV is relatively high across both female condom (73.0 percent) and male condom users (80.8 percent).

With regard to contraception, a similar pattern was found. The female condom scores high in terms of its perceived effectiveness as a contraceptive method among female condom users but lower among male condom users. The perceived effectiveness of the male condom as a contraceptive method is again relatively high among both female condom and male condom users.

With regard to perceived ease of use and affordability, higher percentages of female condom users, male condom users, and non-users alike find the male condom to be easier and more affordable than the female condom. More than 90 percent of both female and male users of the female condom find the male condom easy to use, while 57.0 percent of female and 72.8 percent of male users of the female condom find the female condom easy to use.

Non-users of barrier methods reported lower rates of perceived effectiveness, ease of use, reliability, and affordability of both the female and male condoms, compared to male condom and female condom users. However, even among non-users of barrier methods, the male condom is more often perceived to be effective and easier to use than the female condom. 


\section{Table 5: Perceptions of the female and male condom}

\begin{tabular}{|c|c|c|c|c|c|c|}
\hline \multirow{2}{*}{$\begin{array}{l}\text { Percent (\%) } \\
\text { Variable }\end{array}$} & \multicolumn{2}{|c|}{$\begin{array}{l}\text { Female condom users } \\
(\mathrm{N}=493)\end{array}$} & \multicolumn{2}{|c|}{$\begin{array}{l}\text { Male condom users } \\
(\mathrm{N}=633)\end{array}$} & \multicolumn{2}{|c|}{$\begin{array}{l}\text { Non-users } \\
(\mathrm{N}=624)\end{array}$} \\
\hline & $\begin{array}{l}\text { Male } \\
(\mathrm{N}=256)\end{array}$ & $\begin{array}{l}\text { Female } \\
\mathrm{N}=237 \text { ) }\end{array}$ & $\begin{array}{l}\text { Male } \\
(\mathrm{N}=431)\end{array}$ & $\begin{array}{l}\text { Female } \\
(\mathrm{N}=202)\end{array}$ & $\begin{array}{l}\text { Male } \\
(\mathrm{N}=291)\end{array}$ & $\begin{array}{l}\text { Female } \\
(\mathrm{N}=333)\end{array}$ \\
\hline \multicolumn{7}{|c|}{ Effective as a barrier method to STI/HIV } \\
\hline Female condom & 78.1 & 84.8 & 47.1 & 54.0 & 26.5 & 41.9 \\
\hline Male condom & 73.0 & 75.2 & 80.8 & 80.1 & 46.8 & 60.8 \\
\hline \multicolumn{7}{|c|}{ Effective as a contraceptive method } \\
\hline Female condom & 91.0 & 85.7 & 64.6 & 54.6 & 37.2 & 43.3 \\
\hline Male condom & 85.2 & 81.4 & 91.4 & 91.5 & 70.2 & 64.1 \\
\hline \multicolumn{7}{|l|}{ Easy to use } \\
\hline Female condom & 72.8 & 57.0 & 21.1 & 13.5 & 12.9 & 20.8 \\
\hline Male condom & 93.9 & 90.5 & 91.9 & 91.0 & 58.0 & 54.6 \\
\hline \multicolumn{7}{|l|}{ Reliable } \\
\hline Female condom & 67.2 & 75.7 & 32.5 & 31.5 & 16.0 & 24.3 \\
\hline Male condom & 56.1 & 65.3 & 71.4 & 76.6 & 26. & 39.4 \\
\hline \multicolumn{7}{|l|}{ Affordable } \\
\hline Female condom & 73.2 & 73.6 & 31.1 & 26.7 & 23.2 & 25.1 \\
\hline Male condom & 93.9 & 93.2 & 82.7 & 90.3 & 61.4 & 59.6 \\
\hline
\end{tabular}

Female condom users participating in in-depth interviews reported both advantages and disadvantages to the female condom as compared to the male condom.

For example, several informants reported that they had more "faith" in the female condom because they found it to be "safer" and "stronger" than the male condom and reported that the female condom "slips and breaks less" than the male condom. Several male in-depth interview and focus group participants said that they experience more sexual pleasure with the female rather than the male condom. For example, one in-depth interview participant said that with the female condom, it feels like "I am doing it live." Several women said that they like the feeling of being "more in control" with the female condom, while several men said that they are happy to shift the "responsibility" of condom use to their female partners.

Female condom users participating in the survey were also asked about specific difficulties they may have experienced with the method. Thirty percent of male users and 57.2 percent of female users of the female condom said that they experienced some difficulty with use. When asked about types of difficulties, the most common ones reported by both women and men are similar to those mentioned by qualitative research participants, including problems with insertion, discomfort during sex, noise or squeakiness during use, and excessive lubrication. 
In-depth interview and focus group participants alike reiterated concerns about initial difficulties with inserting the female condom and with discomfort, especially with the inner ring of the female condom, which several people reported as uncomfortable and even painful at times. Additionally, several in-depth interview and focus group participants discussed the excessive oiliness and lubrication of the female condom and how its insertion and use were often time consuming and messy. This issue of over-lubrication is potentially problematic in the Zimbabwean cultural context, where research has documented that some men prefer dry sex. ${ }^{12}$ Only two of the sixteen in-depth interview participants participating in this study reported that they themselves or their partners use any vaginal drying agents. However, one woman reported that her decision to use the female condom was in part determined by whether her partner wanted to have "wet" or "dry" sex, since having dry sex is inhibited by female condom use. Finally, both men and women participating in focus groups and interviews reported being initially surprised by the "large" size of the device, and the fact that it made noise caused some embarrassment among participants. Of the sixteen in-depth interview participants, only three did not report difficulties using the female condom upon initial use. None of the in-depth interview participants reported seeking advice on use from anyone other than their partner. Most participants reported overcoming these difficulties by the third or fourth use.

In summary, female condom users perceive the female condom to be effective and reliable as both an STI/HIV prevention method and a contraceptive method. High percentages of female condom users also find the male condom to be almost equally effective in these areas. However, while high percentages of male condom users perceive the male condom to be effective as both an STI/HIV barrier and a contraceptive method, considerably lower percentages of male condom users perceive the female condom to be effective in these areas. Higher percentages of both female and male condom users also find the male condom easier to use and more affordable than the female condom.

In addition to the questions above about participants' perceptions of the female and the male condom, survey respondents were asked to
${ }^{12}$ van de Wijgert, J. et al. 1996. "Use of intravaginal preparations, presence of lactobacillus in the vagina, and risk for HIV in Zimbabwean women," paper presented at the International Conference on AIDS, Vancouver, Canada, 7-12 July. 
Figure 3: Comparative perceptions of barrier methods

Men $(\mathrm{N}=256) \quad$ Women $(\mathrm{N}=237)$

\section{Easier to introduce}

directly compare several different characteristics of the female and male condoms. For example, survey participants were asked (1) which is easier to introduce to a partner, (2) which they would feel more comfortable buying, and (3) which they would feel more comfortable being seen using by other people. The response of female condom users to these questions is presented in Figure 3.

Overall, between a third and half of female condom users rate both methods "the same" in each of these categories, indicating that many men and women alike find the male and female condom quite comparable. Yet responses vary somewhat by sex. For example, more than half of male users of the female condom find the male condom easier to introduce than the female condom, and more than half said that they would rather be seen with the male than the female condom. Higher percentages of female users of the female condom, however, prefer the female to the male condom for each of the three categories of comparison, demonstrating that men and women have different perceptions of the product. 


\section{With Whom Is the Female Condom Discussed and How Is Its Use Negotiated?}

Participants from all three population groups (female

condom users, male condom users, and non-users) were asked if they had discussed the female condom with any of their partners in the last 12 months. Eighty-three percent of male condom users and 78 percent of non-users surveyed reported that they had heard of the female condom. While awareness of the female condom is high among all three groups, the frequency of specific female condom-related discussions is much higher among female condom users, as would be expected, compared to male condom users and non-users. Table 6 shows the percentage of study participants from each of these three groups who discussed the female condom with different types of partners. These results also demonstrate that female condomrelated dialogue is most prevalent among regular partners, compared to spouses or casual partners, regardless of user group.

\section{Table 6: Percent of participants who discussed the female condom with specific partner types}

\begin{tabular}{|l|l|l|l|}
\hline $\begin{array}{l}\text { Variable } \\
\text { Discussed } \\
\text { female condom with: }\end{array}$ & Percent (\%) & Male condom users & Non-users \\
\hline Spouse & 82.9 & 18.3 & 13.4 \\
& $(206 / 249)$ & $(64 / 352)$ & $(52 / 386)$ \\
\hline Regular partner & 87.3 & 25.7 & 19.2 \\
& $(249 / 285)$ & $(98 / 380)$ & $(26 / 134)$ \\
\hline Casual acquaintance & 46.3 & 8.2 & 7.1 \\
& $(43 / 93)$ & $(21 / 260)$ & $(4 / 54)$ \\
\hline Sex worker & 37.7 & 1.9 & 6.4 \\
& $(14 / 37)$ & $(3 / 179)$ & $(2 / 35)$ \\
\hline
\end{tabular}

Female condom users answered other questions about the discussion and negotiation of female condom use, such as who initiated the discussions, what was discussed when negotiating use, and who eventually decided to use the female condom, in the context of different types of relationships. As documented earlier, the female condom is most often used in the context of marriage and other regular partnerships. Table 7 describes the dynamics and content of female condom negotiation among men and women who reported 
discussing the method with either their spouse or a regular partner in the last 12 months.

Both male and female users of the female condom said that women more than men initiate dialogue on female condom use. Among married female condom users, 42.0 percent of men and 55.1 percent of woman said that it was the woman who began such discussions.

Among female condom users with regular partners, 45.2 percent of men and 72.3 percent of women reported that the female partner initiated discussions on female condom use.

Participants frequently mentioned both pregnancy and disease (STI/HIV) prevention in the discussion and negotiation process of female condom use, according to reports from female condom users. Among married users of the female condom, 82.2 percent of men and 75.0 percent of women reported discussing pregnancy prevention during female condom negotiations. Among female condom users with regular partners, 91.3 of men and 91.1 percent of women reported discussing pregnancy. Disease prevention was also often discussed in the context of female condom negotiations, though slightly less frequently than pregnancy prevention. Among married female condom users, 70.8 percent of women and 65.5 percent of men reported discussing disease prevention. Among female

\section{Table 7: Negotiation dynamics and discussion} content with spouses or regular partners

\begin{tabular}{|c|c|c|}
\hline Variable & Percent & \\
\hline $\begin{array}{l}\text { Discussed } \\
\text { with spouse }\end{array}$ & $\begin{array}{l}\text { Men } \\
(N=116)\end{array}$ & $\begin{array}{l}\text { Women } \\
(\mathrm{N}=90)\end{array}$ \\
\hline $\begin{array}{l}\text { Who initiated discussion: } \\
\text { Man } \\
\text { Woman } \\
\text { Both }\end{array}$ & $\begin{array}{l}35.0 \\
42.0 \\
23.0\end{array}$ & $\begin{array}{l}35.4 \\
55.1 \\
9.5\end{array}$ \\
\hline Discussed pregnancy & 82.2 & 75.0 \\
\hline Discussed disease prevention & 70.8 & 65.5 \\
\hline $\begin{array}{l}\text { Who decided to use: } \\
\text { Man } \\
\text { Woman } \\
\text { Both }\end{array}$ & $\begin{array}{l}26.9 \\
37.3 \\
35.8\end{array}$ & $\begin{array}{l}30.7 \\
32.6 \\
36.7\end{array}$ \\
\hline $\begin{array}{l}\text { Discussed with } \\
\text { regular partner }\end{array}$ & $\begin{array}{l}\text { Men } \\
(N=128)\end{array}$ & $\begin{array}{l}\text { Women } \\
(N=121)\end{array}$ \\
\hline $\begin{array}{l}\text { Who initiated discussion: } \\
\text { Man } \\
\text { Woman } \\
\text { Both }\end{array}$ & $\begin{array}{l}36.7 \\
45.2 \\
18.1\end{array}$ & $\begin{array}{r}18.3 \\
72.3 \\
9.4\end{array}$ \\
\hline Discussed pregnancy & 91.3 & 91.1 \\
\hline Discussed disease prevention & 87.6 & 76.7 \\
\hline $\begin{array}{l}\text { Who decided to use: } \\
\text { Man } \\
\text { Woman } \\
\text { Both }\end{array}$ & $\begin{array}{l}21.1 \\
35.8 \\
43.1\end{array}$ & $\begin{array}{l}11.8 \\
44.3 \\
43.9\end{array}$ \\
\hline
\end{tabular}


condom users with regular partners, 87.6 percent of men and 76.7 percent of women reported discussing STI/HIV/AIDS prevention.

Several women participating in focus group discussions and in-depth interviews mentioned that while they are interested in the female condom for disease prevention, they are not very comfortable discussing this openly with their partner. This sentiment is more prevalent among married women who use the female condom with their husbands, rather than single women who more often use the female condom with regular or casual partners. Married women reported using such alternative negotiation strategies as discussing how sex would be more enjoyable for their husbands with the female rather than the male condom, explaining how they could have sex during menstruation with the female condom, or suggesting the female condom for family planning purposes because of dissatisfaction with hormonal methods.

As to which partner decides on using the female condom, male and female of the female condom users again agree that women more than men decide whether to use the device. However, a considerable percentage of both male and female users of the female condom also reported that both partners jointly decide to use the female condom. The majority of female condom users said that it was the woman alone who obtained the female condom the last time it was used.

Among men, 53.8 percent of married men and 64.6 percent of unmarried men said that their female partner obtained the female condom. Among women, 49.6 percent of married women and 59.5 percent of unmarried women said that they themselves obtained the female condom.

The female condom has sometimes been referred to as an alternative to the male condom for women because it is perceived as female-controlled. ${ }^{13}$ Results from this study show ${ }^{13}$ Elias, C. and C. Coggins. 1996. "Female-controlled methods to prevent sexual transmission of HIV," AIDS 10 that 13 percent of women have reportedly used the female condom without their male partners' knowledge. While this suggests that, for some women, the female condom can be 
female-controlled, in the vast majority of cases the method requires communication with and cooperation from a woman's partner.

Findings from qualitative research suggest that participants have differing views on the ease with which women can negotiate female condom use with their male partners. For example, several single female focus group participants echoed one participant, who said that "women are now independent and are decision makers and are empowered" and hence able to communicate and negotiate use of the female condom. On the same note, one of the single male focus group participants stated, "My girlfriend suggested the female condom.... [T] imes are changing, we the youth must also change with the times."

Yet several other male and female participants offered a different opinion, stating that cultural barriers prevent women from negotiating the female condom because "women are not supposed to talk about the need for sex," hence, women "must not talk about using the female condom because this is suggestive." Many male focus group participants agreed that it is not easy for many women to introduce the female condom, depending on how closely their partner holds to traditional beliefs regarding a woman's role. Both men and women also said that introducing the female condom into a regular partnership or marriage could be seen as a sign of mistrust or infidelity, which is how the male condom is often perceived. Female condom users surveyed were also asked if any of their partners ever opposed using the female condom. Among men, 14.9 percent of married men and 15.4 percent of unmarried men stated that one of their partners had previously opposed female condom use. Among women, 24.4 percent of married women and 22.7 percent of unmarried women reported having a partner who opposes use. Users who reported having a partner who opposes female condom use were also asked what their response was to such opposition. Most participants reported that they used a male condom instead of the female condom. However, among married women in particular, several women whose partner opposed female condom use $(10 / 22)$ said that they had unprotected sex instead.

From the data presented above, discussions and decisions regarding female condom use are most often initiated and made by either women alone or by women and men jointly, rather than men alone. Survey participants frequently reported both pregnancy prevention and disease prevention as topics discussed in the negotiation process. However, pregnancy prevention is reportedly discussed slightly more frequently than disease prevention; this is not surprising, given that the female condom was marketed as a contraceptive sheath. In the majority of instances, it is women alone who obtained the 
female condom the last time it was used. In-depth interview and focus group participants reported additional negotiation strategies associated with the female condom, such as emphasizing increased sexual pleasure, compared to the male condom. Almost a quarter of all women who had used the female condom reported that one of their partners had opposed the method at some point, and several qualitative research participants identified cultural barriers that inhibit dialogue about the female condom for women.

\section{How Consistently Is the Female Condom Used?}

As reported in Table 8, 15.4 percent of men and 16.0 of women surveyed who had ever used the female condom reported always using the method regardless of partner type or marital status. Consistent use is reported much less frequently among female condom users and their spouses (4.2 percent of women and 6.0 percent of men) than among female condom users and their regular partners outside of marriage (20.5 percent of women and 29.9 percent of men). Relatively small numbers of men and women reported having casual partners. Hence, percentages of consistent female condom use among men and women with casual partners such as acquaintances and sex workers are somewhat less meaningful. Reported consistent female condom use with such casual acquaintances varies from 17.5 percent among men to 50.4 percent among women.

Both male and female ever users reported that they used the female condom a median number of 2.0 times during the last three months. However, data were not collected on the number of times participants had sex during the last three months or how long before the interview they first began using the female condom, which would have allowed for a more precise calculation of the percentage of sex acts protected by female condom use. Perhaps due to initial difficulties with use, as described earlier, many users may 
have stopped using the female condom after just one or two experiences with the method.

Inconsistent female condom users were asked how they decided when to use the method within the last three months. Users were given a list of five possible reasons why they decided to use the female condom. The two most common responses were when there was a risk of pregnancy and when there was a risk of disease. Among men, almost equal percentages of inconsistent users stated that they used the female condom to prevent pregnancy rather than such diseases as HIV/AIDS. However, among women, slightly higher percentages of inconsistent users stated that they used the female condom to prevent pregnancy rather than disease.

In-depth interviews also addressed this issue. Several participants provided detailed explanations for inconsistent female condom use. For example, some women reported that they use the female condom only during menstruation so that they and their partner could still have sex, while others described using the female condom during their fertile period for family planning purposes. Additionally, two women reported using the female condom when their husbands come home late at night or when they suspect them of being unfaithful. In these cases, the women use the female condom that day or the following day, but not necessarily consistently thereafter. Price was mentioned as an issue for several respondents who reportedly use the male condom more often than the female condom because it is less expensive.

\section{Table 8: Consistency of female condom use in the last 12 months}

\begin{tabular}{|c|c|c|}
\hline Variable & \multicolumn{2}{|c|}{ Percent (\%) } \\
\hline $\begin{array}{l}\text { Always used female condom } \\
\text { with all partners }\end{array}$ & $\begin{array}{l}\text { Men } \\
(\mathrm{N}=256)\end{array}$ & $\begin{array}{l}\text { Women } \\
(\mathrm{N}=237)\end{array}$ \\
\hline Yes & 15.4 & 16.0 \\
\hline $\begin{array}{l}\text { Used female condom } \\
\text { with spouse }\end{array}$ & $\begin{array}{l}\text { Men } \\
(N=108)\end{array}$ & $\begin{array}{l}\text { Women } \\
(\mathrm{N}=150)\end{array}$ \\
\hline $\begin{array}{l}\text { Always } \\
\text { Usually } \\
\text { Occasionally }\end{array}$ & $\begin{array}{l}6.0 \\
26.9 \\
67.1\end{array}$ & $\begin{array}{l}4.2 \\
18.4 \\
77.4\end{array}$ \\
\hline $\begin{array}{l}\text { Used female condom with } \\
\text { regular partner }\end{array}$ & $\begin{array}{l}\text { Men } \\
(\mathrm{N}=128)\end{array}$ & $\begin{array}{l}\text { Women } \\
(\mathrm{N}=124)\end{array}$ \\
\hline $\begin{array}{l}\text { Always } \\
\text { Usually } \\
\text { Occasionally }\end{array}$ & $\begin{array}{l}29.9 \\
21.1 \\
49.0\end{array}$ & $\begin{array}{l}20.5 \\
30.5 \\
49.0\end{array}$ \\
\hline $\begin{array}{l}\text { Used female condom with } \\
\text { casual acquaintance }\end{array}$ & $\begin{array}{l}\text { Men } \\
(\mathrm{N}=23)\end{array}$ & $\begin{array}{l}\text { Women } \\
(\mathrm{N}=26)\end{array}$ \\
\hline $\begin{array}{l}\text { Always } \\
\text { Usually } \\
\text { Occasionally }\end{array}$ & $\begin{array}{l}17.5 \\
40.7 \\
41.8\end{array}$ & $\begin{array}{l}50.4 \\
22.1 \\
27.5\end{array}$ \\
\hline $\begin{array}{l}\text { Used female condom } \\
\text { with sex worker }\end{array}$ & $\begin{array}{l}\text { Men } \\
(\mathrm{N}=16)\end{array}$ & $\begin{array}{l}\text { Women } \\
(\mathrm{N}=0)\end{array}$ \\
\hline $\begin{array}{l}\text { Always } \\
\text { Usually } \\
\text { Occasionally }\end{array}$ & $\begin{array}{l}17.9 \\
18.3 \\
63.7\end{array}$ & $\overline{\mathrm{NA}}$ \\
\hline
\end{tabular}


Additionally, multivariate logistic regression was done to further examine the determinants of consistent female condom use among all users. The results of this analysis are presented in Table 9, controlling for sex. The selection of variables for final multivariate analysis was based upon the results of bivariate logistic regression as well as tests for collinearity among the independent variables.

Results of this analysis demonstrate that female condom users who do not experience difficulties with use or partner opposition to female condom use are significantly more likely to be consistent users. The strongest determinant of consistent female condom use found in this model is whether the participant continues to use another family planning method apart from the female condom. Female condom users who do not rely on other family planning methods are much more likely to be consistent female condom users than those who also use another method of family planning. Participants who initially began to use the female condom to prevent pregnancy are also more likely to be consistent users, as are married users.

Finally, and potentially more difficult to interpret, is the finding that female condom users with lower levels of formal education (less than or equal to four years of secondary school) are more likely to be consistent users than those with higher levels of formal education (more than four years of secondary school). Further qualitative research is needed to understand the dynamics of female condom use within these sub-groups to assess how educational level may influence consistency of use.

Overall, these findings indicate the need to promote support services for female condom users in order to avoid difficulties that inhibit consistent use, as well as programs to
Table 9: Determinants of consistent female condom use $(\mathrm{N}=410)$

\begin{tabular}{|l|l|l|}
\hline Variables & Odds ratio & Confidence interval \\
\hline $\begin{array}{l}\text { Difficulties with use: } \\
\text { No }\end{array}$ & $4.59^{*}$ & $1.73,12.15$ \\
\hline $\begin{array}{l}\text { No } \\
\text { Continer opposition: } \\
\text { family planning: }\end{array}$ & $8.58^{*}$ & $1.54,47.58$ \\
\hline \begin{tabular}{l} 
No \\
\hline $\begin{array}{l}\text { Initiated female condom use in } \\
\text { order to prevent pregnancy: }\end{array}$
\end{tabular} & $11.57^{*}$ & $4.91,27.22$ \\
\hline Yes & $5.40^{*}$ & $2.42,12.01$ \\
\hline $\begin{array}{l}\text { Marital status (reference married): } \\
\text { Single }\end{array}$ & & $2.46,26.00$ \\
\hline $\begin{array}{l}\text { Sex (reference male): } \\
\text { Female }\end{array}$ & $8.38^{*}$ & $2.00,9.59$ \\
\hline $\begin{array}{l}\text { Education (reference more than } 4 \\
\text { years of secondary school): }\end{array}$ & .95 & $.42,2.15$ \\
\hline $\begin{array}{l}\text { years of secondary } \\
*\end{array}$ & & \\
\hline
\end{tabular}

$*=$ p-value $<.05 ;$ Nagelkerke "R-squared" $=.456$ 
facilitate partner communication, given that partner opposition is also a significant determinant of consistent use.

\section{Is the Female Condom a Substitute for the Male Condom?}

If current consistent female condom users were formerly consistently protected by the male condom and simply switched to the female condom for reasons of novelty or personal taste, then one conclusion might be that the female condom is merely a substitute for the male condom. In this situation, the female condom does not provide additional protection to persons at risk of HIV/STI infection who would otherwise go unprotected by a barrier method. The questions posed in this study do not fully address these questions. For example, female condom users were asked if they currently use the female condom consistently across all partner types but were not asked if they previously used the male condom consistently across all partner types, making it difficult to compare consistent protection between the two methods. However, the current data provide us with an initial examination of this issue and stimulate important questions for further research.

Table 10 shows the percentages of male and female users of the female condom who were using family planning before using the female condom and what type of family planning they were using. Among men, 95.4 percent of married men and 85.4 percent of unmarried men had used family planning before using the female condom. Among women, 78.3 percent of married women and 90.7 percent of unmarried women had also used other methods of family planning prior to using the female condom. The majority of both male and female users of the female condom who had previously used family planning said that they had either used the male condom or the pill in the past. 
Female condom users were also specifically asked about their patterns of male condom use. As a form of family planning, 71.5 percent of married and 83.9 percent of unmarried male users of the female condom had used the male condom prior to using the female condom. In comparison, 36.1 percent of married and 63.1 percent of unmarried female users of the female condom had used the male condom as a method of family planning in the past. However, when asked if they had used a male condom for any reason (not just for family planning) before using the female condom, these percentages rose. Among male users of the female condom, 92.2 percent of married and 97.0 percent of unmarried users had used a male condom before the female condom. Among female users of the female condom, 72.4 percent of married and 92.0 percent of unmarried users had used a male condom at least once prior to female condom use.

The data reveal that relatively high percentages (more than 90 percent) of married and unmarried men as well as unmarried women had used a male condom prior to female condom use. However, a high percentage of married women (27.6 percent) had never used a male condom before they used the female condom.

Users of the female condom were also asked whether they intend to use the male condom or the female condom in the

\section{Table 10: Past and future family planning and barrier method practices}

\begin{tabular}{|c|c|c|c|c|}
\hline \multirow{2}{*}{$\begin{array}{l}\text { Percent }(\%) \\
\text { Variable }\end{array}$} & \multicolumn{2}{|c|}{ Men $(\mathrm{N}=256)$} & \multicolumn{2}{|c|}{ Women $(\mathrm{N}=237)$} \\
\hline & $\begin{array}{l}\text { Married } \\
(\mathrm{N}=155)\end{array}$ & $\begin{array}{l}\text { Unmarried } \\
(\mathrm{N}=101)\end{array}$ & $\begin{array}{l}\text { Married } \\
(\mathrm{N}=98)\end{array}$ & $\begin{array}{l}\text { Unmarried } \\
(\mathrm{N}=139)\end{array}$ \\
\hline \multicolumn{5}{|c|}{ Prior family planning and barrier method practices } \\
\hline $\begin{array}{l}\text { Used method of family planning } \\
\text { before female condom }\end{array}$ & 95.4 & 85.4 & 78.3 & 90.7 \\
\hline $\begin{array}{l}\text { Used pill as a family planning } \\
\text { before female condom }\end{array}$ & 53.9 & 18.9 & 41.6 & 31.7 \\
\hline $\begin{array}{l}\text { Used male condom as family } \\
\text { planning before female condom }\end{array}$ & 71.5 & 83.9 & 31.6 & 63.1 \\
\hline $\begin{array}{l}\text { Used male condom as family } \\
\text { planning or in general prior to } \\
\text { female condom }\end{array}$ & 92.2 & 97.0 & 72.4 & 92.0 \\
\hline \multicolumn{5}{|c|}{ Intended future use of female condom } \\
\hline $\begin{array}{l}\text { Intends to continue with } \\
\text { female condom }\end{array}$ & 78.5 & 79.1 & 54.7 & 78.3 \\
\hline $\begin{array}{l}\text { Intends to continue with } \\
\text { male condom }\end{array}$ & $\begin{array}{l}77.8 \\
(113 / 146)\end{array}$ & $\begin{array}{l}75.5 \\
(70 / 93)\end{array}$ & $\begin{array}{l}39.6 \\
(32 / 80)\end{array}$ & $\begin{array}{l}64.4 \\
(77 / 120)\end{array}$ \\
\hline
\end{tabular}


future. Among male users of the female condom, similar percentages of married and unmarried men reported that they intend to use both the female condom and the male condom (approximately 80 percent). However, among women, higher percentages of both married (54.7 percent) and unmarried women (78.3 percent) intend to use the female condom in the future, in comparison with the male condom (39.6 percent of married and 64.4 percent of unmarried women). Married women were the least likely of the sub-groups to report intent to continue using the female condom.

The higher rate of intended future use of the female condom among unmarried women is interesting, raising the question of why higher percentages of unmarried versus married women intend to use the female condom in the future. Unmarried women in regular partnerships may have higher levels of self-efficacy and relationship power, lower levels of perceived intimacy toward their partners, and/or higher perceived need for pregnancy and disease prevention. Further research is needed to examine such questions, since many of these variables were not included in this study.

Table 11 creates a comparison between prior consistent male condom use and current consistent female condom use among female condom users. Findings from this comparison reveal that consistent condom use was higher for prior male condom use than current female condom use. Despite this finding, overall protection with a barrier method did not necessarily decrease among female condom users after initiation of the method, due to their continued use of the male condom in addition to the female condom. For example, 93.8 percent of inconsistent female condom users who had used the male condom prior to female condom use continued to use the male condom even after initiation of female condom use. 
Qualitative research findings reinforce this point. The majority of female condom users who had used the male condom previously reported alternating between male and female condom use, instead of relying on the female condom alone. Participants said that female versus male condom use is determined by several different types of factors, including what is available that night, what the male partner wants to use that night, whether the woman is in her fertile period, and whether the woman is menstruating. Additionally, several male users of the female condom participating in in-depth interviews reported using female condoms with their wives and regular partners, while continuing to use male condoms with casual partners and sex workers.

Approximately 16 percent of all female condom users stated that they currently use the female condom every time they have sex, regardless of partner type. While the question of prior consistent male condom

Table 11: Prior male condom use among current female users

\begin{tabular}{|c|c|c|c|c|}
\hline Variable/ & \multicolumn{2}{|l|}{ Men $(\mathrm{N}=256)$} & \multicolumn{2}{|l|}{ Women $(\mathrm{N}=237)$} \\
\hline Per partner type: & $\begin{array}{l}\text { Current female } \\
\text { condom use }\end{array}$ & $\begin{array}{l}\text { Prior male } \\
\text { condom use }\end{array}$ & $\begin{array}{l}\text { Current female } \\
\text { condom use }\end{array}$ & $\begin{array}{l}\text { Priormale } \\
\text { condom use }\end{array}$ \\
\hline Spouse & $(\mathrm{N}=108)$ & $(\mathrm{N}=104)$ & $(\mathrm{N}=150)$ & $(\mathrm{N}=66)$ \\
\hline $\begin{array}{l}\text { Always } \\
\text { Usually } \\
\text { Occasionally }\end{array}$ & $\begin{array}{l}6.0 \\
26.9 \\
7.1\end{array}$ & $\begin{array}{l}27.4 \\
36.2 \\
36.4\end{array}$ & $\begin{array}{l}4.2 \\
18.4 \\
77.4\end{array}$ & $\begin{array}{l}24.7 \\
22.6 \\
52.7\end{array}$ \\
\hline Regular partner & $(\mathrm{N}=128)$ & $(\mathrm{N}=132)$ & $(\mathrm{N}=124)$ & $(\mathrm{N}=114)$ \\
\hline $\begin{array}{l}\text { Always } \\
\text { Usually } \\
\text { Occasionally }\end{array}$ & $\begin{array}{l}29.9 \\
21.1 \\
49.0\end{array}$ & $\begin{array}{l}71.0 \\
17.8 \\
11.2\end{array}$ & $\begin{array}{l}20.5 \\
30.5 \\
49.0\end{array}$ & $\begin{array}{l}61.6 \\
25.9 \\
12.4\end{array}$ \\
\hline $\begin{array}{l}\text { Casual } \\
\text { acquaintance }\end{array}$ & $(\mathrm{N}=23)$ & $(\mathrm{N}=55)$ & $(\mathrm{N}=26)$ & $(\mathrm{N}=26)$ \\
\hline $\begin{array}{l}\text { Always } \\
\text { Usually } \\
\text { Occasionally }\end{array}$ & $\begin{array}{l}17.5 \\
40.7 \\
41.8\end{array}$ & $\begin{array}{l}80.6 \\
16.4 \\
3.0\end{array}$ & $\begin{array}{l}50.4 \\
22.1 \\
27.5\end{array}$ & $\begin{array}{l}87.5 \\
12.5 \\
0.0\end{array}$ \\
\hline Sex worker & $(\mathrm{N}=16)$ & $(\mathrm{N}=28)$ & $(\mathrm{N}=0)$ & $(\mathrm{N}=0)$ \\
\hline $\begin{array}{l}\text { Always } \\
\text { Usually } \\
\text { Occasionally }\end{array}$ & $\begin{array}{l}17.9 \\
18.3 \\
63.7\end{array}$ & $\begin{array}{l}80.0 \\
7.8 \\
12.2\end{array}$ & NA & NA \\
\hline
\end{tabular}
use across partner type was not asked, the study does provide data on prior consistent male condom use per four principal partner types (spouse, regular partner, casual acquaintance, and sex worker) in the last 12 months. Thus, prior consistent male condom use among current consistent female condom users can be examined for participants who reported having these partner types. Rates of prior consistent male condom use among current consistent female condom users with such partner types were the following: 6/9 or 66.7 percent among those with a spouse, $38 / 45$ or 84.4 percent among those with a regular partner, $7 / 8$ or 87.5 percent among those with a casual acquaintance, and $3 / 3$ or 100 percent among those who had sex with a sex worker. In total, 52/65 or 80.0 percent of current consistent female condom users were using male condoms consistently prior to female condom use within the context of these four partnership types. Thus, $13 / 65$ or 20 percent of current consistent female condom users who had previously used the male condom gain additional protection against pregnancy and disease by integrating female and male condom use. 


\section{Discussion and Recommendations}

The following discussion and programmatic and research recommendations are presented under each of the research questions that guided the study.

Who uses the female condom in Zimbabwe?

Results of this study indicate that female condom users are generally better educated and of higher socioeconomic status than male condom users and non-users of either method. It is not surprising that persons with higher levels of education and socioeconomic status may be more inclined initially to try the product or in a better position financially to acquire the product and negotiate its use. An important issue for program planners, however, is ensuring access to the female condom for people from all economic and educational strata.

\section{Recommendation: Program planners and researchers should continue to monitor who uses the female condom in Zimbabwe over time. If significantly greater percentages of people with higher socioeconomic status or more formal education continue to use the product at higher rates than people of lower socioeconomic status, then the price of the product may be too high and/or spe- cial support services may be needed to facilitate access, negotia- tion, or correct use of the female condom among persons with lower levels of resources and education.}

Apart from education and socioeconomic status, marital status also differs across user groups in this study. For example, a higher percentage of female users of the female condom are single compared to female users of the male condom and non-users. This finding leads to several questions: Do single women have greater levels of empowerment compared to married women, making them more interested in or able to negotiate female condom use? Or is it the nature of the relationships that single women have with their male sexual partners compared to the relationships (e.g., greater intimacy, commitment, desire for children) between married couples that may account for higher levels of use among single women? With regard to men, a higher percentage of male users of the female condom are married compared to male users of 
the male condom. This finding may reflect the attraction of younger men with higher numbers of sexual partners to the male condom, given its historic use as a disease prevention method. Additional qualitative research may be needed to understand these findings in further detail.

Recommendation: Program planners and marketers of the female condom in Zimbabwe may want to consolidate their support base among single women and married men who are already using the female condom in higher numbers, but should also develop more refined social marketing strategies and support services to reach groups who are potentially underrepresented among current female condom consumers, such as married women and single men.

Given that female condom users reportedly had more than one sexual partner on average in the last 12 months and/or perceive themselves to be at some risk for HIV infection, the female condom seems to have significant potential as an HIV/STI prevention mechanism among this group. An additional issue important to program planners with regard to risk perception is the issue of married women who currently do not use any barrier method. Twenty-six percent of these women perceive themselves at high risk for HIV infection, but are currently not using any barrier method.

Recommendation: Future female condom media and educational campaigns as well as empowerment initiatives should also address the needs of married women who are currently not using any barrier methods, many of whom reported having only one sexual partner but fear HIV infection due to their male partner's sexual behavior.

With which types of partners is the female condom used?

Study findings reveal that the female condom is generally used in the context of a regular partnership or marriage. This finding is consistent with the marketing strategy employed by PSI in Zimbabwe that promoted the product specifically for couples in long-term relationships.

Recommendation: In order to expand female condom use to populations other than spouses and regular partners in Zimbabwe, additional marketing messages need to be developed and adjustments made to the product's current distribution plan. 
Why do people use the female condom?

Reported reasons for initial female condom use include novelty, pregnancy prevention, and HIV prevention. However, reasons for ongoing female condom use focus mostly on pregnancy and HIV prevention. Given that the female condom was originally marketed as a contraceptive sheath in Zimbabwe, slightly more study participants reported using the method for pregnancy rather than HIV prevention.

\section{Where do people learn about and obtain the female condom?}

Study participants generally first learned about the female condom from media messages on the radio and TV. However, more than half the participants said that they first heard about the female condom from friends or relatives. This finding indicates the potential importance of promoting the female condom through peer educators, given the level of diffusion of information among social contacts documented in the study sample. Additionally, more than half of female users of the female condom said that they heard about female condoms at a clinic, hospital, or doctor's office. The majority of study participants reported that they last obtained the female condom at a local pharmacy, indicating the important role that could be played by the health care sector.

\section{Recommendation: Study findings suggest that training peer educators as well as clinicians and pharmacists to provide potential and current female condom users with information about the product and support services may be an effective means of increasing correct and continued use of the method.}

Such support mechanisms are clearly needed, given that the majority of female condom users said that the only information that they received on how to use the female condom was from the package itself. This lack of information, support, and follow-up with female condom users is reflected in the high percentage of users reporting difficulty with its use, a critical issue that must be addressed in future interventions in order to sustain use and promote consistency of use.

What attitudes and perceptions exist about the female condom and what difficulties are associated with use?

Female condom users perceive the female condom to be effective and reliable as both an STI/ HIV prevention method and a contraceptive method. Qualitative research findings suggest 
that many participants prefer the female to the male condom because of its durability and because it promotes greater sexual pleasure than the male condom. Female qualitative research participants also reported feeling "more in control" with the female versus the male condom. However, a higher percentage of female users find the male condom easier to use and more affordable than the female condom. Common reported difficulties with the female condom include initial difficulties with insertion of the device as well as complaints that the female condom is over-lubricated and noisy.

\section{Recommendation: Program planners need to address insertion difficulties associated with the female condom as well as complaints that the female condom is over-lubricated and noisy, in order to ensure correct and contin- ued use of the product.}

With whom is the female condom discussed and how is its use negotiated?

Higher percentages of study participants discuss the method with their regular rather than their casual sexual partners. High percentages of female condom users reported discussing both pregnancy and HIV/AIDS/STI prevention with their partners. However, qualitative research findings reveal that some female condom users (women in particular) do not negotiate female condom use on the basis of HIV prevention, even though they are acutely aware of its effectiveness as both a pregnancy and an HIV prevention method, in order to avoid conflict or stigma associated with HIV/AIDS and barrier methods.

Recommendation: Based on study findings, a variety of female condom communication and negotiation strategies should be discussed with potential female condom users. Program planners should seek to work with groups of women in particular to strategize jointly on the most appropriate ways to negotiate female condom use based on participants' relational, familial, and cultural contexts.

In terms of who decides to use the female condom, this study found that while women more often than men are the ones who decide whether to use the female condom, an almost equal number of decisions are made jointly between both partners. Thirteen percent of female 
condom users in this study said that they use the product without their partner's knowledge. This finding suggests that the female condom may be an option for some women who need or want to use an HIV prevention method without their partner's knowledge.

Recommendation: What is known from the current data, however, is that female condom use, in the vast majority of cases, still involves communication, negotiation, and agreement with one's partner. Hence, female condom programming must assist users, and women in particular, to be prepared for these tasks, equipping them with the necessary skills and tools for such challenging processes.

Thus the question remains: Is the female condom any easier than the male condom for women to negotiate, given such cultural constraints and the potential need for agreement on its use? As described earlier, some women feel more able to negotiate the female condom than the male condom. Several female participants feel that the female condom is more easily negotiated as a family planning method than the male condom and is also easier to negotiate because some men find sex more pleasurable with the female versus the male condom. Hence, according to in-depth interview and focus group participants, the female condom does offer an alternative method of HIV prevention to some women who would otherwise not be interested in or able to negotiate male condom use.

How consistently is the female condom used?

One of the most important findings of this study relates to the consistency of female condom use. Approximately 16 percent of all study participants reported using the female condom consistently across partner types. Consistency of use is higher in the context of nonmarital regular partnerships and casual relationships compared to marital relationships.

Recommendation: The lowest rate of consistent female condom use is among married women and their spouses. Additionally, married women are also least likely to intend to use the female condom in the future, despite being the group with the least experience with the male condom in the past 


\section{and hence the group with the most potential for newly acquired protection with the female condom. Whether married women are less interested in or less able to use the female condom consis- tently with their husbands is an important question for future research that would establish whether specific support services are needed for married women.}

It is important to contextualize these findings about consistency of female condom use. The goal of most reproductive health and HIV prevention programs is to ensure client satisfaction and protection by offering a continuum of options and methods. For HIV prevention, the goal of many programs is to increase the rate of protected sexual encounters rather than the rate of consistent female condom use alone.

For those interested in female condom use alone, the analyses presented above provide an initial indication of factors that affect ability to achieve this intention. However, in future studies it will be important to document the change in the rate of sex acts protected by either barrier method as a result of access to female condoms. This point is reinforced by a recent study conducted in two urban STI clinics in Alabama. Within the study, more than 700 patients had tried the female condom, but after six months only 8 percent were using the device consistently. Despite relatively low rates of consistent female condom use, the study reports increases in the overall rate of protected sex, indicating that access and promotion of female condom use in addition to male condom use is associated with higher rates of consistent barrier protection. ${ }^{14}$

Additionally, a randomized community trial of female condoms used as a backup to male condoms shows a 34 percent decrease in STI incidence and a 25 percent decline in unprotected sex acts among female sex workers and clients in Thailand. ${ }^{15}$ Such research findings underscore the idea that both female and male condoms are needed to prevent the spread of HIV and STIs, rather than one or the other.

\footnotetext{
${ }^{14}$ Macaluso, M. et al. 2000. "Female condom use among women at high risk for sexually transmitted disease," Family Planning Perspectives 32(3): 138-44
}

\footnotetext{
15 AIDS Weekly Plus. 1998. “U.N. Promotes Female Condom Against AIDS in Africa," May 4: 16.
} 


\section{Is the female condom a substitute for the male condom?}

Study findings indicate that the female condom is providing new and additional protection from HIV/STI to some study participants. Among female condom users, approximately 11 percent of all participants, 16 percent of all women, and 28 percent of married women had never used the male condom prior to using the female condom. For these people, the female condom thus provides a new method of barrier protection previously not achieved. Additionally, 20 percent of consistent female condom users who had previously used the male condom were not consistent male condom users in the past, indicating that for this group the female condom provides additional protection from HIV/STI.

In conclusion, this study provides important data to program planners and policymakers who are charged with reducing HIV/STI risk among women and men in Zimbabwe. An important next step will be to operationalize the recommendations set forth in this report and then conduct a longitudinal study that follows participants over time to assess the impact of improved female condom access and support services on the overall rate of protected sex acts. 
AIDSCAP Women's Initiative. 1997. The Female Condom: From Research to the Marketplace. Arlington, VA: Family Health International.

AIDS Weekly Plus. 1998. “U.N. Promotes Female Condom Against AIDS in Africa,” May 4: 16.

Elias, C. and C. Coggins. 1996. "Female-controlled methods to prevent sexual transmission of HIV," AIDS 10 Suppl. 3: S43-51.

Family Health International. 2000. Kenya: Female Condom Use and the Incidence of Sexually Transmitted Infections. AIDSCAP Project. Arlington, VA: Family Health International.

Kabira, W. et al. 1997. The Female Condom as a Female-Controlled Protective Method: Nairobi, Kenya. Arlington, VA: Family Health International.

Kalckmann, A. et al. 1997. The Female Condom as a Female-Controlled Protective Method: São Paulo, Brazil. Arlington, VA: Family Health International.

Macaluso, M. et al. 2000. "Female condom use among women at high risk for sexually transmitted disease," Family Planning Perspectives 32(3): 138-44.

Olayinka, B. et al. 2000. “Generational differences in male sexuality that may affect Zimbabwean women's risk for sexually transmitted diseases and HIV/AIDS," East African Medical Journal 77(2):93-7.

Population Services International (PSI). 1999. A Case Study of “Care: contraceptive sheath.” Harare, Zimbabwe: PSI.

Ray, S. et al. 1995. "Acceptability of the female condom in Zimbabwe: Positive but male-centered responses," Reproductive Health Matters 5: 494-503.

Rogers, C. et al. 1997. "The female condom: counseling women in successful use of the newest method 
of barrier protection from STD/HIV that puts control into the hands of the woman," paper presented at the National Conference on Women and HIV, Pasadena, California, 4-7 May.

Tsopotsa, T. 1998. Marketing the Female Condom in Zimbabwe: New Methods and Challenges. New York: Population Council.

Trussell, J. et al. 1994. "Comparative contraceptive efficacy of the female condom and other barrier methods," Family Planning Perspectives 26(2): 66-72.

UNAIDS (Joint United Nations Programme on HIV/AIDS). 2000. Report on the Global HIV/AIDS Epidemic. Geneva, Switzerland: UNAIDS.

van de Wijgert, J. et al. 1996. "Use of intravaginal preparations, presence of lactobacillus in the vagina, and risk for HIV in Zimbabwean women," paper presented at the International Conference on AIDS, Vancouver, Canada, 7-12 July.

Winter, J. 1997a. "Female condom sales beat forecast by 10 times," AIDS Analysis Africa 7(5): 9. 1997b. "Social marketing of condoms (female, too) gets going (again) in Zimbabwe," AIDS Analysis Africa 7(2): 6.

World Health Organization (WHO) and UNAIDS. 2000. The Female Condom: A Guide for Planning and Programming. Geneva, Switzerland: UNAIDS.

Xu, J.X. et al. 1998. "User acceptability of a female condom (Reality) in Shanghai," Advances in Contraception 14(4): 193-99. 


\section{Horizons}

Horizons is a global operations research project designed to:

- Identify and test potential strategies to improve HIV/AIDS prevention, care, and support programs and service delivery.

- Disseminate best practices and utilize findings with a view toward scaling up successful interventions.

For more information, please contact:

Horizons Project, Communications Unit 4301 Connecticut Avenue, NW Suite 280 Washington, DC 20008 USA

Tel: 202-237-9400

Fax: 202-237-8410

Email: horizons@pcdc.org www.popcouncil.org/horizons/horizons.html 